\title{
Degradable and injectable poly(aldehyde guluronate) hydrogels for bone tissue engineering
}

\author{
Kuen Yong Lee, ${ }^{1,2,3}$ Eben Alsberg, ${ }^{1}$ David J. Mooney ${ }^{1,2,3}$ \\ ${ }^{1}$ Department of Biomedical Engineering, University of Michigan, Ann Arbor, Michigan 48109 \\ ${ }^{2}$ Department of Chemical Engineering, University of Michigan, Ann Arbor, Michigan 48109 \\ ${ }^{3}$ Department of Biologic \& Materials Sciences, University of Michigan, Ann Arbor, Michigan 48109
}

Received 17 July 2000; revised 2 January 2001; accepted 6 February 2001

\begin{abstract}
Degradable and injectable hydrogels may be ideal for bone-tissue engineering, especially in the craniofacial region because of the ease of access for injection. Alginate hydrogels potentially could be used as injectable cell delivery vehicles, but they exhibit a limited range of mechanical properties and uncontrollable disintegration time. Therefore we synthesized new hydrogels, composed of poly(aldehyde guluronate) (PAG) and adipic acid dihydrazide, that have a wide range of mechanical stiffness and controllable degradation rate. MC3T3-E1 cells adhered and multiplied on PAG hydrogels in vitro. When primary rat
\end{abstract}

calvarial osteoblasts were mixed with PAG hydrogels and subcutaneously injected into the backs of mice, mineralized bone tissues were formed 9 weeks following implantation. These hydrogels may find wide utility as an injectable delivery system for bone precursor cells as well as for other applications in tissue engineering. (C) 2001 John Wiley \& Sons, Inc. J Biomed Mater Res 56: 228-233, 2001

Key words: degradation; injectable; poly(aldehyde guluronate); hydrogel; bone-tissue engineering

\section{INTRODUCTION}

Tissue engineering is a recently developed field that aims to replace lost tissue or whole organ function. ${ }^{1,2}$ Tissues or organs can be engineered with many different strategies. A particularly attractive approach utilizes a combination of a patient's own cells and a polymeric construct. In this approach, tissue-specific cells are isolated from a small tissue biopsy and expanded in vitro. The cells subsequently are placed onto a polymeric construct that acts as a synthetic extracellular matrix. The cell-polymer construct delivers the cells to the desired site in the body, offers a space for tissue regeneration, and potentially controls the structure and function of the engineered tissue. ${ }^{3,4}$

Correspondence to: D.J. Mooney, Department of Chemical Engineering, University of Michigan, 3074 H.H. Dow Bldg, 2300 Hayward Street, Ann Arbor, Michigan 48109-2136; email: mooneyd@umich.edu

Contract grant sponsor: National Institutes of Health; contract grant number: R01-DE13033

Contract grant sponsor: Curis

Contract grant sponsor: National Institutes of Health [graduate fellowship (EA)]; contract grant number: T32DE07057

(c) 2001 John Wiley \& Sons, Inc.
There have been many demands for reconstructing bone defects, especially in the craniofacial region as a result of congenital defects, trauma from accidents, and disease. It would be ideal to access these sites using minimally invasive techniques that would leave minimal scarring and would minimize patient discomfort. Tissue engineering utilizing hydrogels may offer an attractive approach for bone regeneration and integration with the host tissue in the craniofacial region. Hydrogels already have found numerous applications in drug delivery ${ }^{5-8}$ and generally are considered biocompatible as they have structural similarity to the macromolecular-based components in the body. ${ }^{9}$ They have been used in cell transplantation because they can be injected into the body in a minimally invasive manner for tissue engineering applications. ${ }^{10-12}$ This delivery form for a cell-polymer construct may lessen a patient's trauma, pain, and the cost of a procedure. ${ }^{13}$

Alginate has been widely utilized in various biomedical applications due to its easy gelation, biocompatibility, and low toxicity. ${ }^{14,15}$ Alginate forms hydrogels via ionic crosslinking with divalent cations. However, ionically crosslinked hydrogels have a limited range of mechanical properties and disintegration behavior. Therefore, by covalent crosslinking, we re- 
cently synthesized new hydrogels composed of alginate derivatives. ${ }^{16}$ These covalently crosslinked hydrogels had a wide range of mechanical stiffness and a degradation rate dependant on the controllable crosslinking density, ${ }^{17}$ both of which are useful for drug-delivery applications. ${ }^{8}$ In this paper we describe degradable and injectable hydrogels prepared from poly(aldehyde guluronate) (PAG) and their initial use in bone-tissue engineering. PAG was obtained from alginate by acid hydrolysis followed by oxidation, and it easily formed hydrogels with adipic acid dihydrazide as a covalent crosslinking molecule. PAG hydrogels showed degradation rates ranging from a few days to several weeks, depending on the crosslinking density, and they were found to be useful for bonetissue engineering.

\section{MATERIALS AND METHODS}

\section{Preparation of PAG and hydrogel formation}

Polyguluronate (PG) initially was isolated from sodium alginate (Protanal LF 20/60, Pronova Co., Norway) by acid hydrolysis and collected at $\mathrm{pH} 2.85 .{ }^{17,18}$ The precipitate was re-dissolved in double-distilled water at neutral $\mathrm{pH}$, and activated carbon was added for further purification. The solution was stirred thoroughly for $30 \mathrm{~min}$, filtered to remove the activated carbon, precipitated by ethanol, and lyophilized (weight-average molecular weight, $\mathrm{M}_{\mathrm{w}}=7000$; polydispersity index, $\left.M_{w} / M_{n}=1.60\right)$. PG then was oxidized with $0.25 \mathrm{M}$ of sodium periodate solution (Aldrich, Wisconsin) at room temperature. The ratio between the guluronate unit and the periodate was 1:1. An equimolar amount of ethylene glycol was added after $19 \mathrm{~h}$ to stop the oxidation reaction. The resultant solution was filtered, dialyzed (molecular weight cut-off, 1000, Spectra/Por ${ }^{\circledR}$ ) for 3 days, and lyophilized $\left(\mathrm{M}_{\mathrm{w}}=5700, \mathrm{M}_{\mathrm{w}} / \mathrm{M}_{\mathrm{n}}=1.64\right) .{ }^{17}$ The degree of oxidation of PAG was determined to be $66.5 \%$, from a trinitrobenzene sulfonic acid (TNBS) assay. ${ }^{17}$

A $20 \mathrm{wt} \%$ solution of poly(aldehyde guluronate) (PAG) was mixed with different amounts of adipic acid dihydrazide (Aldrich, Wisconsin) for in vitro characterization studies, placed into 48-well tissue culture plates, and incubated at room temperature for $4 \mathrm{~h}$ to form hydrogels. All the solutions were prepared in Dulbecco's modified Eagle's medium (DMEM; Gibco BRL, Gaithersburg, Maryland), and $\mathrm{pH}$ was adjusted to 7.4 before mixing. The final concentration of PAG in the hydrogel before swelling was $6 \mathrm{wt} \%$, and AAD concentration varied from 100 to $200 \mathrm{mM}$. All the hydrogels were immersed in DMEM ( $\mathrm{pH} 7.4$ ) at $37^{\circ} \mathrm{C}$ for $24 \mathrm{~h}$ to reach complete hydration.

\section{Characterization of PAG hydrogels}

The coupling reaction between aldehyde and hydrazide groups was confirmed by disappearance of a symmetric vi- brational band of the aldehyde group at $1735 \mathrm{~cm}^{-1}$ and appearance of a carbonyl band of the hydrazide at $1658 \mathrm{~cm}^{-1}$ from the FT-IR spectra, as previously reported. ${ }^{17}$ PAG hydrogels (11 $\mathrm{mm}$ in diameter and $3 \mathrm{~mm}$ thick) were prepared $(n=4)$, and their elastic moduli were measured from a compression test using a mechanical tester (MTS Bionix 100, MTS Systems, France). The deformation rate was $0.5 \mathrm{~mm} /$ $\mathrm{min}$, and the diameter of the indenter was $3.15 \mathrm{~mm}$. To determine gel swelling, the hydrogels were swollen in DMEM ( $\mathrm{pH} 7.4$ ) for $24 \mathrm{~h}$ at $37^{\circ} \mathrm{C}$, excess water on the hydrogels was removed, and the gels were weighed. The swelling ratio $(Q)$ was defined as the mass ratio of absorbed water and the dried gel.

\section{Degradation of PAG hydrogels}

Thirty-two disks of PAG hydrogels crosslinked with different amounts of AAD were prepared, immersed in DMEM $(\mathrm{pH} 7.4)$, and incubated at $37^{\circ} \mathrm{C}$ under $5 \% \mathrm{CO}_{2}$ atmosphere for varying times. The dry weight of four samples was analyzed at each time point by removing the samples from the DMEM and drying them in a lyophilizer. All the experiments were done under sterile conditions to prevent bacterial and fungal contamination. Statistical analysis was carried out using Instat software, and a Student's $t$ test was performed to compare samples at different time points or conditions.

\section{In vitro cell adhesion}

MC3T3-E1 mouse calvarial preosteoblasts, a generous gift from Dr. M. Kumegawa (Josai Dental University, Japan), were used to perform cell adhesion experiments on PAG hydrogels. The MC3T3 cells were cultured in $\alpha$-Minimum Essential Media ( $\alpha$-MEM; Hyclone, Logan, Utah) containing $10 \%$ fetal calf serum (Hyclone) and 100 units $/ \mathrm{mL}$ of penicillin-streptomycin (Gibco BRL). PAG hydrogels with 150 $\mathrm{mM}$ of AAD were placed in 24-well plates and pretreated with $0.5 \mathrm{~mL}$ of serum-containing media. MC3T3 cells were seeded on the gels at a density of $10 \times 10^{3}$ cells $/ \mathrm{cm}^{2}$. The medium was changed every other day and photographs were taken at $\times 200$ magnification $24 \mathrm{~h}$ and 5 days following seeding. The cells were rinsed with phosphate-buffered saline solution before the photographs were taken, and cells at the 5-day time point were stained with 3-(4,5-dimethylthiazol-2-yl)-2,5-diphenyltetrazolium bromide (MTT) to improve cell visibility.

In vivo animal study

PAG hydrogels with 100 or $200 \mathrm{mM}$ of AAD were prepared in a 1-mL plastic syringe and kept at $4^{\circ} \mathrm{C}$ during cell isolation. Primary rat calvarial osteoblasts were harvested using a modified method reported by Pockwinse et al. ${ }^{19}$ Briefly, cells were obtained from newborn (fewer than 3 
days old) Lewis rat pups (Harlan Sprague-Dawley, Indianapolis, Indiana). The pups were doused with 95\% ethanol, decapitated, and the calvaria were isolated. The calvaria were stored in Hanks' balanced salt solution (HBSS; Gibco BRL) until the isolation was completed. Upon completion of the harvest, the calvaria were rinsed three times with HBSS and once with serum-free $\alpha$-MEM with 100 units $/ \mathrm{mL}$ of penicillin-streptomycin and $50 \mathrm{mg} / \mathrm{L}$ of gentamicin (Gibco BRL). Digestion media, which consisted of $2 \mathrm{mg} / \mathrm{mL}$ of collagenase $\mathrm{P}$ (Boehringer-Mannheim, Indianapolis, Indiana) and $0.25 \%$ trypsin (Gibco BRL) in serum-free $\alpha$-MEM, was added at approximately 2 times the volume of the calvaria. The tubes were capped and placed in a $37^{\circ} \mathrm{C}$ water bath with gentle shaking for $20 \mathrm{~min}$. The medium was removed, new digestion medium was added, and digestion was allowed for $40 \mathrm{~min}$. The medium again was removed, new digestion medium was added, and digestion was allowed for $90 \mathrm{~min}$. After this final digestion, the cells were resuspended in $\alpha$-MEM with $10 \%$ fetal calf serum. The cells subsequently were spun down and the supernatant removed. Cells were mixed with PAG hydrogels using two syringes and a female connector to achieve a cell concentration of $40 \times 10^{6}$ cells / mL. Two hundred $\mu \mathrm{L}$ of PAG hydrogel/cell construct were injected subcutaneously into the backs of 4-5-week-old SCID mice (Taconic Farms Inc., Germantown, New York). Hydrogels without cells were used as a control. The mice were sacrificed after 9 weeks, fixed in formalin, embedded in paraffin, sectioned, and stained using standard hematoxylin and eosin or von Kossa protocols for microscopic observation $(n=2)$. NIH guidelines for the care and use of laboratory animals (NIH Publication £85-23 Rev 1985) were observed.

\section{RESULTS}

PAG was prepared from alginate by acid hydrolysis and oxidation, and formed hydrogels in the presence of AAD as a covalent crosslinking molecule (Fig. 1). PAG hydrogels were prepared with different amounts of AAD to make gels with different degradation rates. The elastic moduli of the hydrogels crosslinked with 100 and $200 \mathrm{mM}$ of AAD were $18.3 \pm 1.4$ and $4.3 \pm 0.6$

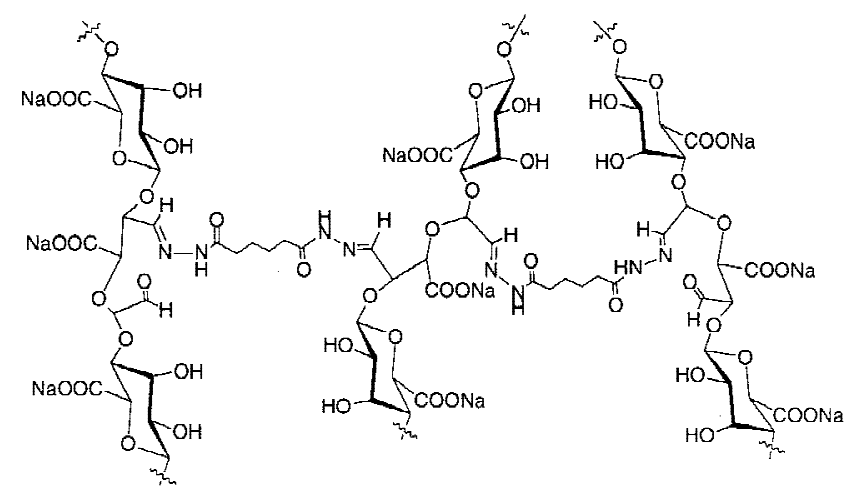

Figure 1. Chemical structure of poly(aldehyde guluronate) hydrogels crosslinked with adipic acid dihydrazide.
$\mathrm{kPa}$, respectively, as measured by compression testing. The swelling ratio $(Q)$ of the hydrogels crosslinked with 100 and $200 \mathrm{mM}$ of AAD in DMEM $\left(\mathrm{pH} 7.4,37^{\circ} \mathrm{C}\right)$ were $13.2 \pm 0.3$ and $16.0 \pm 0.6$, respectively (Fig. 2). Degradation of PAG hydrogels was monitored by the weight loss of gels in the media over time. Hydrogels crosslinked with $100 \mathrm{mM}$ of AAD were completely degraded after 5 days. However, no statistically significant weight loss of hydrogels crosslinked with $200 \mathrm{mM}$ of AAD was observed even after 4 weeks ( $17 \pm 9 \%$ loss of initial weight), irrespective of their initially low modulus and high swelling ratio (Fig. 3). This will be discussed more fully later.

Cell culture and transplant experiments with bone precursor cells on PAG hydrogels were carried out to investigate the cellular interaction of osteoblasts with PAG hydrogels. MC3T3 cells spread extensively on the surface of PAG hydrogels within $24 \mathrm{~h}$ following cell seeding, and they proliferated to reach confluency after 5 days (Fig. 4). PAG hydrogels were mixed with rat calvarial-derived osteoblasts and subcutaneously injected into the dorsal region of mice to determine if bone tissue could be formed with these polymers. No bone formation was observed for cells injected with PAG hydrogels crosslinked with $100 \mathrm{mM}$ of AAD, perhaps due to the rapid degradation of hydrogels (Fig. 3). However, osteoblasts injected with PAG hydrogels crosslinked with $200 \mathrm{mM}$ of AAD formed bone tissues after 9 weeks (Fig. 5). The bone tissue formed was present throughout the entire implant but was clearly most prominent in the outer one-third of the implantation site. This result likely is due to the initial lack of vascularization within the implant following injection. The engineered bone tissues were substantially mineralized, as confirmed by selective

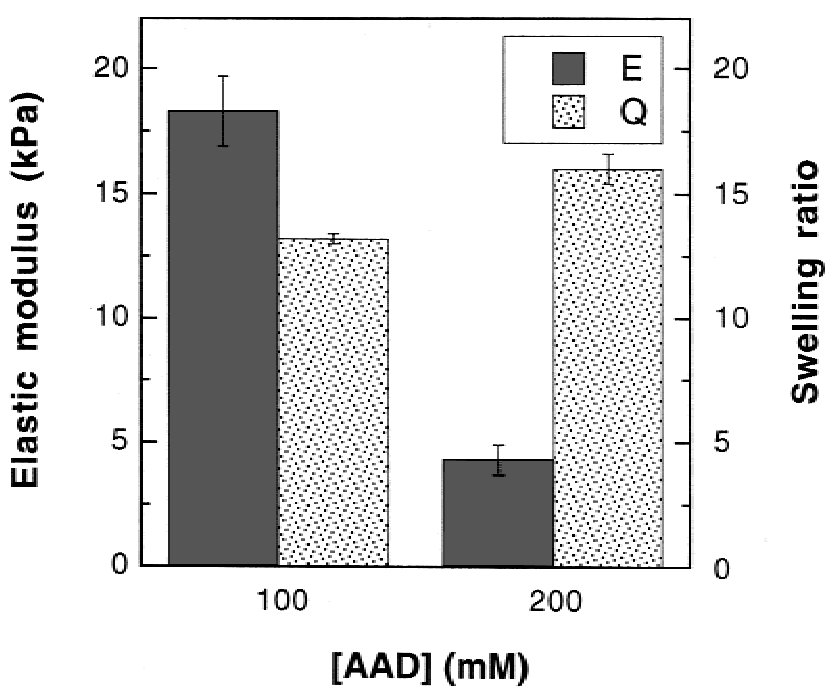

Figure 2. Elastic modulus $(E)$ and swelling ratio $(Q)$ of PAG hydrogels crosslinked with 100 and $200 \mathrm{mM}$ of AAD.

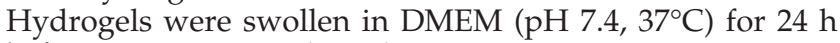
before measurement $(n=4)$. 


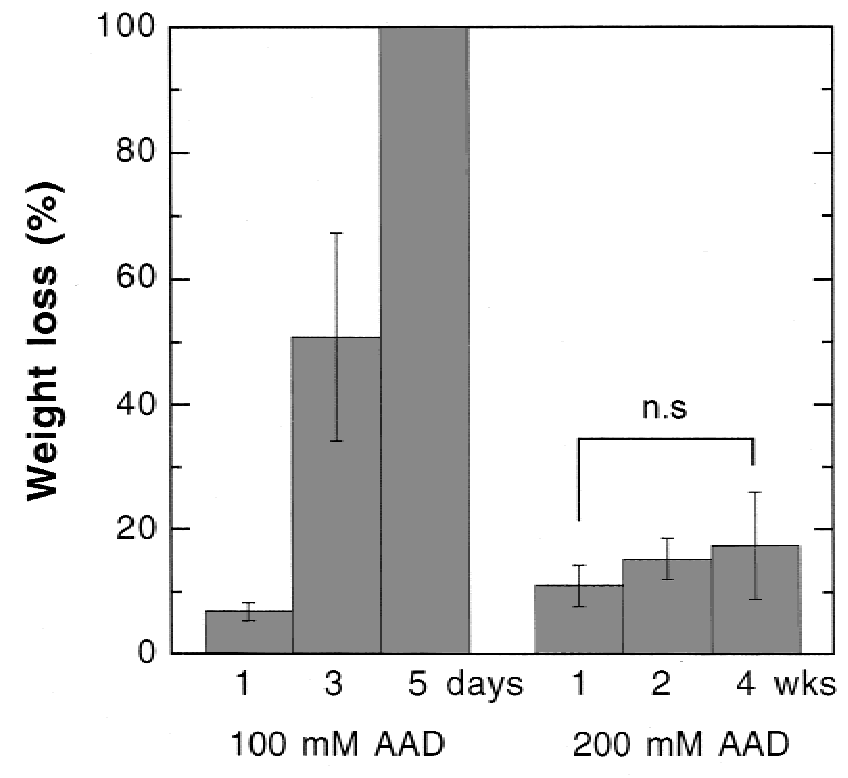

Degradation time

Figure 3. Weight loss of PAG hydrogels crosslinked with 100 and $200 \mathrm{mM}$ of AAD during degradation. Hydrogels were immersed in DMEM $\left(\mathrm{pH} 7.4,37^{\circ} \mathrm{C}\right)$ under $5 \% \mathrm{CO}_{2}$ during degradation. n.s. indicates no statistical difference in mass between any of the time points for these gels $(n=4)$.

staining using the von Kossa reagent [Fig. 5(c)]. No bone tissue was observed in control hydrogels injected without osteoblasts even though they showed the same degradation behavior compared to those injected with cells (data not shown).

\section{DISCUSSION AND CONCLUSIONS}

Degradable and injectable hydrogels for tissue engineering applications successfully were prepared from poly(aldehyde guluronate) by covalent crosslinking. Osteoblasts readily adhered to PAG hydrogels in vitro and formed mineralized bone tissue in the dorsal region of mice when transplanted on specific PAG hydrogels. This study may provide a first step in the development of these degradable and injectable hydrogels for bone-tissue engineering.

There are many candidate hydrogels that could be utilized as a degradable and injectable cell transplantation vehicle. However, there have been few reports on bone-tissue engineering utilizing injectables. Reports to date have utilized poly(propylene fumarate)/ $\beta$-tricalcium phosphate composites ${ }^{20}$ and photopolymerizable polyanyhydrides, ${ }^{21}$ likely due to their osteoconductive properties. We previously reported the synthesis and characteristics of PAG hydrogels derived from alginate. ${ }^{16,17}$ PAG can be prepared by a simple method and readily form gels by reaction with

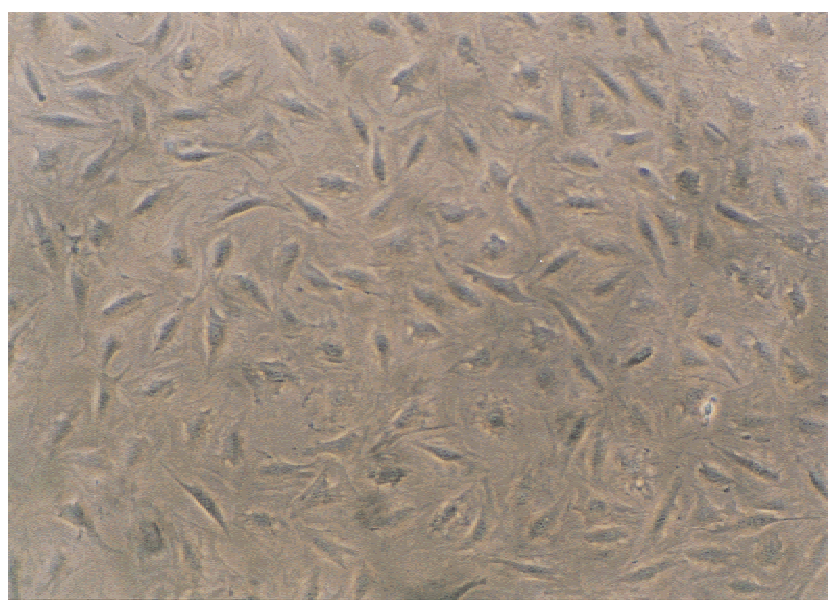

(a)

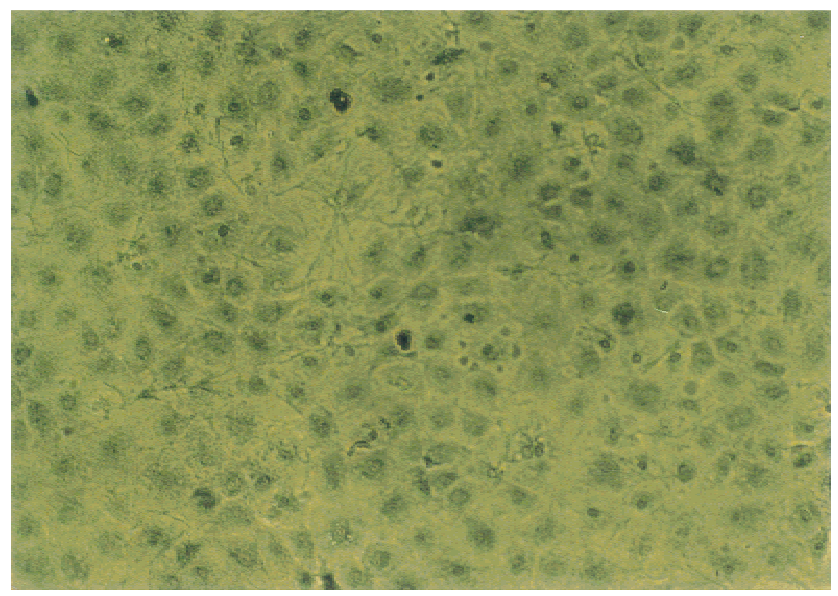

(b)

Figure 4. Photomicrographs of MC3TC cells adhered to the surface of PAG hydrogels crosslinked with $150 \mathrm{mM}$ of AAD after (a) $24 \mathrm{~h}$ and (b) 5 days of culture. Original magnification $\times 200$. [Color figure can be viewed in the online issue, which is available at www.interscience.wiley.com.]

bifunctional crosslinking molecules. Aldehyde groups in PAG are very reactive toward hydrazide groups of AAD compared to carboxyl groups, and thus PAG reacts with AAD rapidly without any catalyst. The resultant hydrazone bonds are labile to hydrolysis even at neutral $\mathrm{pH}$, and this makes PAG hydrogels degradable in a controllable manner, depending on the crosslinking density. For bone-tissue engineering, polymeric constructs should degrade in a controlled manner to allow the bone-remodeling process. ${ }^{22}$ Therefore PAG hydrogels were considered to be suitable for this application due to their controllable degradation rate over time as well as to their biocompatibility. These gels would not be suitable for the regeneration of bones for load-bearing applications due to the requirement of high moduli (e.g., $\sim 100 \mathrm{MPa}$ for the trabecular bone in the human mandible and $20 \mathrm{GPa}$ for the human cortical bone) $)^{23,24}$ unless fixation also was provided.

One interesting feature of these PAG hydrogels is 


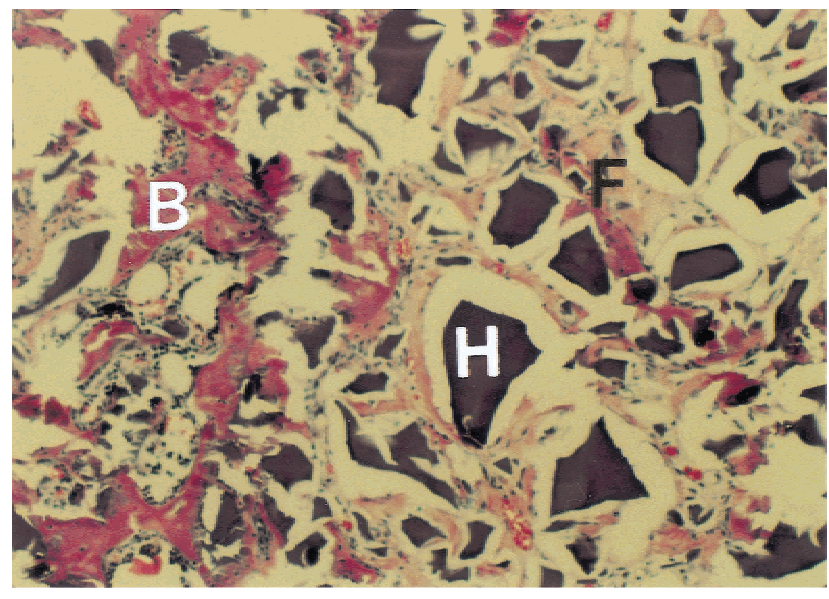

(a)

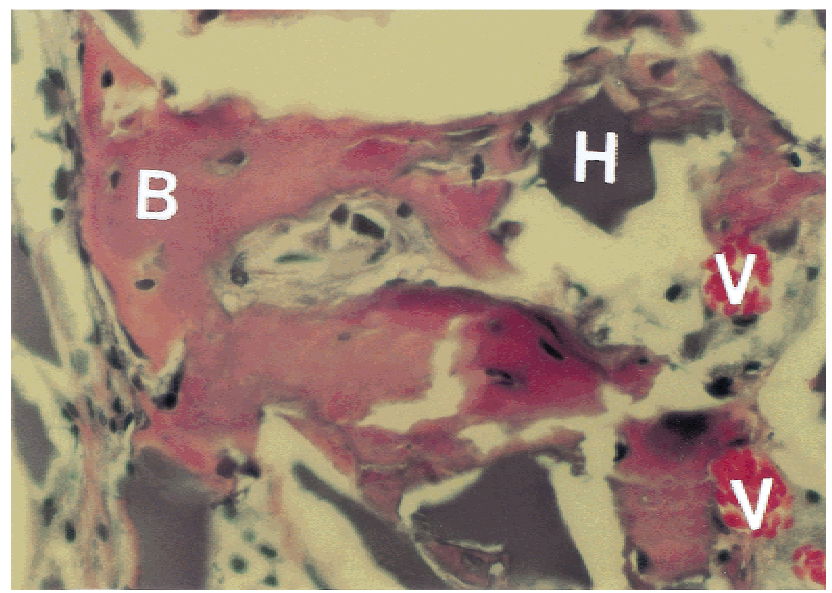

(b)

that mechanical properties and degradation time can be decoupled. ${ }^{17}$ Those two properties generally are coupled to each other as both typically rise and fall together with the crosslinking density of the gels. For example, PAG hydrogels crosslinked with $100 \mathrm{mM}$ of AAD showed coupled mechanical stiffness and degradation rate, which means that both features were proportional to each other. However, PAG hydrogels crosslinked with $200 \mathrm{mM}$ of AAD decoupled the rigidity and the degradation rate. Although PAG hydrogels crosslinked with $200 \mathrm{mM}$ of AAD showed significantly less modulus than those crosslinked with $100 \mathrm{mM}$ of AAD $(p<0.05)$, no statistically significant degradation of the gels was observed over 4 weeks (Figs. 2 and 3). We previously have demonstrated that hydrogels synthesized with excess amounts of crosslinking molecules contain significant network defects in terms of dangling single-end molecules, resulting in low moduli of gels. ${ }^{17}$ However, this large number of dangling single-end molecules allows a recrosslinking reaction of the PAG strand following hydrolysis of the initial crosslinking sites. Therefore, hydrogels with many dangling single-end molecules may have no significant change in net crosslinking density over time and will very slowly degrade. We

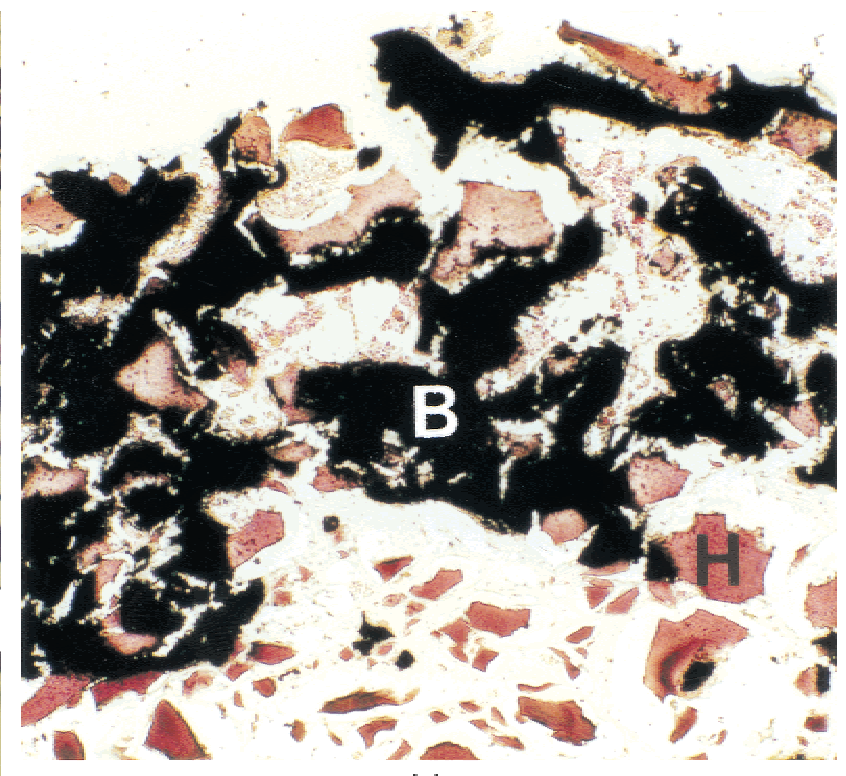

(c)

Figure 5. Photomicrographs of representative tissue sections of osteoblasts transplanted in PAG hydrogels crosslinked with $200 \mathrm{mM}$ of AAD. Tissue sections were taken after 9 weeks and stained with $(a, b)$ hematoxylin and eosin and (c) the von Kossa reagent to highlight mineralized tissue. Original magnifications were $(a, c) \times 100$ and (b) $\times 400$. The photomicrographs have labels for remaining PAG hydrogel $(\mathrm{H})$, newly formed bone tissue (B), fibrous tissue $(\mathrm{F})$, and blood vessels $(\mathrm{V})$. [Color figure can be viewed in the online issue, which is available at www.interscience.wiley.com.]

previously have shown that PAG hydrogels crosslinked with $200 \mathrm{mM}$ of AAD contain a high number of dangling single-end molecules compared to other gels. It therefore is not surprising that these hydrogels exhibited a retarded degradation, irrespective of their low initial modulus and high swelling ratio (Figs. 2 and 3).

A clear challenge for this approach-for any approach - to engineering large bone defects is adequate vascular invasion from the host tissue. This is evident from our findings that indicate bone formation only in the exterior portions of the scaffold (Fig. 5). This limited bone formation is likely a result of mass transport limitations immediately following cell-polymer injections. ${ }^{25}$ Similar findings have been reported in past studies of bone cell transplantation. ${ }^{26}$ In the future, simultaneous delivery of angiogenic agents from the polymer construct may allow the vascularization process to be enhanced. ${ }^{27}$ Delivery of osteoinductive agents such as bone morphogenetic protein (BMP), basic fibroblast growth factor (bFGF), insulin-like growth factor (IGFs), transforming growth factor- $\beta$ (TGF- $\beta$ ), platelet-derived growth factor (PDGF), or plasmid DNA also potentially may improve this approach to bone-tissue engineering. ${ }^{28,29}$ 


\section{References}

1. Langer R, Vacanti JP. Tissue engineering. Science 1993;260:920926.

2. Mooney DJ, Mikos AG. Growing new organs. Sci Am 1999;280: 60-65.

3. Kim B-S, Mooney DJ. Development of biocompatible synthetic extracellular matrices for tissue engineering. TIBTECH 1998; 16:224-230.

4. Marler JJ, Upton J, Langer R, Vacanti JP. Transplantation of cells in matrices for tissue regeneration. Adv Drug Deliv Rev 1998;33:165-182.

5. Brondsted H, Kopecek J. Hydrogels for site-specific drug delivery to the colon-In vitro and in vivo degradation. Pharm Res 1992;9:1540-1545.

6. Inoue T, Chen GH, Nakamae K, Hoffman AS. A hydrophobically modified bioadhesive polyelectrolyte hydrogel for drug delivery. J Controlled Release 1997;49:167-176.

7. Peppas NA, Keys KB, Torres-Lugo M, Lowman AM. Poly(ethylene glycol)-containing hydrogels in drug delivery. J Controlled Release 1999;62:81-87.

8. Bouhadir KH, Kruger GM, Lee KY, Mooney DJ. Sustained and controlled release of daunomycin from cross-linked poly(aldehyde guluronate) hydrogels. J Pharmaceut Sci 2000;89:910-919.

9. Jhon MS, Andrade JD. Water and hydrogels. J Biomed Mater Res 1973;7:509-522.

10. Jen AC, Wake MC, Mikos AG. Hydrogels for cell immobilization. Biotech Bioeng 1996;50:357-364.

11. West JL, Hubbell JA. Polymeric biomaterials with degradation sites for proteases involved in cell migration. Macromolecules 1999;32:241-244.

12. Rowley JA, Madlambayan G, Mooney DJ. Alginate hydrogels as synthetic extracellular matrix materials. Biomaterials 1999; 20:45-53.

13. Jeong B, Bae YH, Lee DS, Kim SW. Biodegradable block copolymers as injectable drug-delivery systems. Nature 1997;388: 860-862.

14. Draget KI, Skjåk-Bræk G, Smidsrød O. Alginate based new materials. Int J Biol Macromol 1997;21:47-55.

15. Paige KT, Cima LG, Yaremchuk MJ, Schloo BL, Vacanti JP, Vacanti CA. De novo cartilage generation using calcium alginate-chondrocyte constructs. Plast Reconstr Surg 1996;97:168178.

16. Bouhadir KH, Hausman DS, Mooney DJ. Synthesis of crosslinked poly(aldehyde guluronate) hydrogels. Polymer 1999;40: 3575-3584.
17. Lee KY, Bouhadir KH, Mooney DJ. Degradation behavior of covalently cross-linked poly(aldehyde guluronate) hydrogels. Macromolecules 2000;33:97-101.

18. Haug A, Larsen B, Smidrød O. A study of the constitution of alginic acid by partial acid hydrolysis. Acta Chem Scand 1966; 20:183-190.

19. Pockwinse SM, Wilming LG, Conlon DM, Stein GS, Lian JB. Expression of cell growth and bone specific genes at single cell resolution during development of bone tissue-like organization in primary osteoblast culture. J Cell Biochem 1992;49:310323.

20. Peter SJ, Miller ST, Zhu G, Yasko AW, Mikos AG. In vivo degradation of a poly(propylene fumarate)/ $\beta$-tricalcium phosphate injectable composite scaffold. J Biomed Mater Res 1998; 41:1-7.

21. Anseth KS, Shastri VR, Langer R. Photopolymerizable degradable polyanhydrides with osteocompatibility. Nat Biotechnol 1999;17:156-159.

22. Yaszemski MJ, Payne RG, Hayes WC, Langer R, Mikos AG Evolution of bone transplantation: Molecular, cellular and tissue strategies to engineer human bone. Biomaterials 1996;17: 175-185.

23. Misch CE, Qu ZM, Bidez MW. Mechanical properties of trabecular bone in the human mandible: Implications for dental implant treatment planning and. surgical placement. J Oral Maxillofac Surg 1999;57:700-706.

24. Hoffmeister BK, Smith SR, Handley SM, Rho JY. Anisotropy of Young's modulus of human tibial cortical bone. Med Biol Eng Comput 2000;38:333-338.

25. Colton CK. Implantable biohybrid artificial organs. Cell Transplant 1995;4:415-436.

26. Ishaug-Riley SL, Crane GM, Gurlek A, Miller MJ, Yasko AW, Yaszemski MJ, Mikos AG. Ectopic bone formation by marrow stromal osteoblast transplantation using poly(DL-lactic-coglycolic acid) foams implanted into the rat mesentery. J Biomed Mater Res 1997;36:1-8.

27. Sheridan MH, Shea LD, Peters MC, Mooney DJ. Bioadsorbable polymer scaffolds for tissue engineering capable of sustained growth factor delivery. J Controlled Release 2000;64:91-102.

28. Giannobile WV. Periodontal tissue engineering by growth factors. Bone 1996;19:23S-37S

29. Winn SR, Uludag H, Hollinger JO. Sustained release emphasizing recombinant human bone morphogenetic protein-2. Adv Drug Del Rev 1998;31:303-318. 